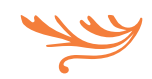

\author{
Klassikon paluu -sarjassa esitellään teoksia, jotka ovat \\ olleet merkityksellisiä aikuiskasvatuksen tutkijoille ja \\ ammattilaisille opinnoissa, tutkimuksessa ja työssä. \\ Sarjan avaavat Juha Suoranta ja Nina Hjelt esseillään \\ kasvatusfilosofi Paulo Freiresta, joka perusti \\ pedagogiikkansa kriittiseen lukutaitoon.
}

\section{SORRETTUJEN PEDAGOGIIKAN HENKI ON OHJANNUT TYÖTÄNI}

BRASILIALAISEN KASVATUSFILOSOFIN ja aikuiskasvattajan Paulo Freiren (1921-1997) pääteos Sorrettujen pedagogiikka julkaistiin vuonna 1968. Se käännettiin lukuisille kielille, ja siitä tuli yksi yhteiskuntatieteiden tunnetuimpia teoksia maailmassa (Green 2016).

Luin Freiren ajatuksista 1980-luvun lopulla tenttikirjasta. Siinä Freiren kirjan lähtökohdaksi esitetään ajatus "ihmisestä subjektina, joka toiminnallaan kehittää kulttuuria ja historiaa” (Eskola 1982, 173). Freiren pääteoksen luin muutamaa vuotta myöhemmin.

Kirjassaan Freire kuvaa Brasilian kahtiajakautuneeksi, sortajien ja sorrettujen yhteiskunnaksi, ja asettuu sorrettujen puolelle. Hän esittää teorian, miten sorretut voivat tiedostaa sortoyhteiskunnan piirteet, vapautua sortajistaan ja vapauttaa samalla sortajansa. Vapautuminen yhteiskunnalliseksi toimijaksi alkaa kriittisen lukutaidon oppimisesta, joka on sorrettujen pedagogiikan perusta. Tiedostettuaan sortotilanteensa kriittisen lukutaidon avulla sorretut kykenevät liittymään yhteen poliittiseksi voimaksi, tulevat tietoiseksi luokka-asemastaan ja kehittyvät luokaksi itselleen.

Yhdessä vallankumousjohtajien kanssa sorretut

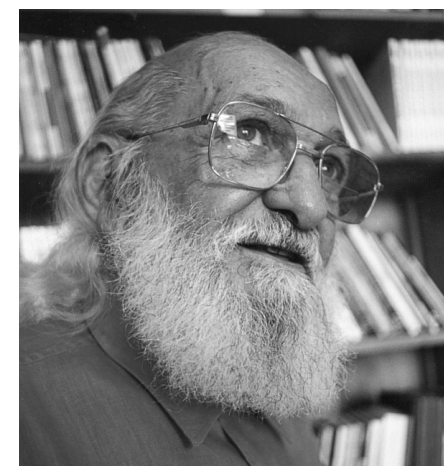

Paulo Freire

pystyvät vapautumaan yhteiskunnallisesta ja taloudellisesta herruudesta ja löytämään suuren humanistisen ja historiallisen tehtävänsä inhimillisen maailman rakentajina. "Sorrettujen pedagogiikan eli omaan vapaustaisteluunsa osallisten ihmisten pedagogiikan juuret ovat juuri tässä”, Freire $(2005,55)$ toteaa.

Nämä olivat kaltaiselleni työläiskodissa kasvaneelle opiskelijalle kirjan tärkeimpiä ajatuksia. Ja ne ovat niitä yhä. Ajatus sorretuista muutosvoimana pani käsittämään, että kasvatus ja koulutus sekä niitä tutkivat tieteet ovat syvästi poliittisia ilmiöitä.

Sorrettujen pedagogiikka ei sijoitu millekään nimenomaiselle tieteenalalle, vaan se on kirjoitettu ensi sijassa 
köyhille ja syrjäytetyille sekä heidän parissaan työtä tekeville. Kasvatustieteissä teos synnytti 1970-luvulla kriittisen pedagogiikan tutkimusperinteen, jossa tarkastellaan kasvatuksen tasa-arvon ja vallankäytön kysymyksiä sekä pyritään edistämään ihmisoikeuksia ja demokraattista sosialismia.

FREIREN KIRJA on saattanut tuhansia ihmisiä yhteen ja synnyttänyt yhteyksiä heidän välilleen. Myös minä olen solminut Sorrettujen pedagogiikan välityksellä kotimaisia ja ulkomaisia tutkimusyhteyksiä, joita ajattelen eräänlaisena maailmanlaajuisena Freire-opistona. Kutsuin vuonna 1999 vieraakseni professori Peter McLarenin, joka oli tuntenut Freiren henkilökohtaisesti ja valmisteli tuolloin kirjaa Freiren ja Ernesto "Che" Guevaran vallankumouksellisesta pedagogiikasta (McLaren 2000). Myöhemmin kirja ilmestyi suomeksi nimellä Che, Freire ja vallankumouksen pedagogiikka (McLaren 2009). McLarenin vierailu ja tuolloin syntynyt ystävyys vaikuttivat merkittävästi opetus- ja tutkimustyöhöni.

Suomalaiseen keskusteluun sorrettujen pedagogiikan toivat Aino Hannulan (2000) väitöskirja, Kriittinen pedagogiikka -teos (Giroux \& McLaren 2001) ja Sorrettujen pedagogiikan suomennos (Freire 2005). Freiren teos tunnetaan Suomessa hyvin suomennoksen ja Freiren ajattelua esittelevien muiden teosten perusteella (esim. Kurki 2002; Suoranta 2005; Suoranta \& Ryynänen 2014; Nivala \& Ryynänen 2019). Sitä käytetään paljon myös opinnäytteissä ja tieteellisissä julkaisuissa. Maailmalla Freiren kirjaa luetaan ja tutkitaan ahkerasti (esim. Peters \& Besley 2015; Darder 2018; Torres 2019; Kirylo 2020).

Kasvatus-lehti julkaisi vuonna 2006 kriittisen pedagogiikan teemanumeron, jossa Freiren ajatuksilla on keskeinen asema. Numeron toimittamisen aikaan työskentelin Minnesotan yliopiston sosiologian laitoksen vierailevana professorina ja törmäsin Freiren vaikutukseen myös siellä. Sosiologi Michael Burawoy mainitsi Sorrettujen pedagogiikan esitelmässään, jonka aiheena oli julkinen sosiologia. Freiren hengessä hän korosti sosiologian opettamisen olevan parhaimmillaan sarja "dialogeja meidän ja opiskelijoidemme välillä, opiskelijoiden ja heidän omien kokemustensa välillä, opiskelijoiden kesken ja lopulta opiskelijoiden ja yliopiston ulkopuolisten yleisöjen välillä”. (Burawoy
2006, 265, myös Burawoy \& von Holdt 2012, luku 5). Kiinnostuin julkisesta sosiologiasta, ja olen opettanut sitä Tampereen yliopiston yhteiskuntatieteilijöille vuodesta 2009 lähtien joitakin välivuosia lukuun ottamatta. Keväällä 2019 kurssimme päälukemistona oli Sorrettujen pedagogiikka.

MAAILMALLE ON vuosien aikana syntynyt useita Freirekeskuksia: jotkin niistä toimivat yliopistojen yhteydessä, toiset ovat organisoituneet järjestöjen yhteyteen. Koska Pohjoismaissa ei ollut tällaista keskusta, perustin sellaisen Tampereen yliopiston kasvatustieteiden laitokselle (https://paulofreirefinland.wordpress.com). Keskuksen avajaisesitelmän piti syksyllä 2007 Peter McLaren otsikolla "Paulo Freire and Critical Pedagogy in the Times of Neoliberal Terror".

Seuraavina kahtena kesänä keskuksen puitteissa järjestettiin kriittisen pedagogiikan kesäkoulut, jotka keräsivät Tampereelle Freiren ajatuksista kiinnostuneita tutkijoita ja väitöskirjojen tekijöitä monesta yliopistosta. McLaren toimi niissä yhtenä opettajana. Järjestelyihin osallistuivat Tampereen yliopiston kasvatustieteiden laitoksen lisäksi Jyväskylän yliopiston kasvatustieteiden laitos ja Nuorisotutkimusseuran Nuorisotutkimusverkosto.

Kesäkoulujen ja Kasvatustieteen päivien kriittisen pedagogiikan teemaryhmien esitysten pohjalta toimitettiin Kriittisen pedagogiikan kysymyksiä -kirjasarja (Aittola, Eskola \& Suoranta 2007; Lanas, Niinistö \& Suoranta 2008; Moisio \& Suoranta 2009), jota oli vuoden 2019 loppuun mennessä ladattu 20000 kertaa.

PAULO FREIREN OPIT omaksuttiin osaksi Brasilian vasemmistolaista politiikkaa jo 1960-luvun alussa. Hänen suunnittelemillaan lukutaitokampanjoilla pyrittiin parantamaan maan köyhien elinoloja ja saamaan heistä vasemmistolaisen demokratian kannattajia. Maan sotilaalliselle ja taloudelliselle valtaeliitille tämä kehityssuunta ei sopinut, ja se teki vallankaappauksen. Freire otettiin tutkintavankeuteen, ja päästyään vapaaksi hän pakeni Chileen. Uudessa kotimaassaan hän löysi Georg Wilhelm Friedrich Hegelin (1770-1831) ja Karl Marxin (1818-1883), joiden ajattelun ja omien sortokokemustensa pohjalta hän kirjoitti pääteoksensa.

Freiren kokemukset sorrosta ja maanpaosta palautuivat mieleeni, kun vuonna 2009 autoin karkotta- 
misvaarassa ollutta alaikäistä turvapaikanhakijaa jäämään Suomeen. Ajattelin tuolloin Freiren kokemaa kohtaloa ja hänen sanojaan, joiden mukaan "täyden ihmisyyden tavoittelu ei voi toteutua eristyksissä tai henkilökohtaisesti, vaan toverillisesti ja solidaarisesti" (Freire 2005, 92). Koska maailma ei ole oikeudenmukainen, vaikeissa tilanteissa olevien ihmisten auttaminen on tärkeää (Suoranta 2010, 67).

Demokraattisen sivistysliiton kesäpäivillä elokuussa 2017 Vähäjärven lomakodissa Lautsiassa puhuin Freiren ja Marxin suhteesta. Tapahtuman jälkeen liiton opintojohtaja kysyi, olinko ajatellut kirjoittaa kirjaa Freirestä. Sellaista hänen mukaansa tarvittaisiin. Olin vastikään saanut valmiiksi kirjan sosiologi C. Wright Millsistä (Suoranta 2017) ja päätin kokeilla, miten Freirestä kirjoittaminen sujuisi samantapaisella otteella. Kirjan suunnitelmaa laatiessani huomasin, etten tiennyt, miten Freirestä kehittyi vallankumouksellinen pedagogi. Tästä kysymyksestä syntyi kirja Paulo Freire. Sorrettujen pedagogi (Suoranta 2019).

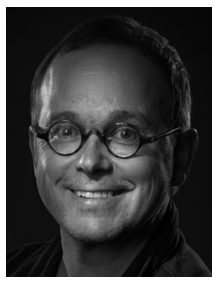

JUHA SUORANTA

$K T$, aikuiskasvatuksen professori Tampereen yliopisto

(D) https://orcid.org/0000-00025206-0115

\section{LÄHTEET}

Aittola, T. Eskola, J. \& Suoranta, J. (toim.) (2007). Kriittisen pedagogiikan kysymyksiä. Tampere: Tampereen yliopisto. http://urn.fi/urn:isbn:978-951-44-7166-7.

Eskola, A. (1982). Vuorovaikutus, muutos, merkitys. Helsinki: Tammi.

Burawoy, M. (2006). Julkisen sosiologian puolustus. Sosiologia 43(4), 259-286.

Burawoy, M. \& Holdt, von (2012). Conversations with Bourdieu: The Johannesburg Moment. http://burawoy. berkeley.edu/Books/Bourdieu.SA/Conversation\%205.pdf.

Darder, A. (2018). The Student Guide to Freire's Pedagogy of the Oppressed. London: Bloomsbury Academic.

Freire, P. (2005). Sorrettujen pedagogiikka. Suom. J. Kuortti. Toim. T. Tomperi. Tampere: Vastapaino.

Giroux, H. \& McLaren, P. (2001). Kriittinen pedagogiikka. Suom. J. Vainonen. Tampere: Vastapaino.

Green, Elliott (2016). What are the most-cited publications in the social sciences (according to Google Scholar)? https://blogs.Ise.ac.uk/impactofsocialsciences/2016/05/12/ what-are-the-most-cited-publications-in-the-socialsciences-according-to-google-scholar (3.1.2020).

Hannula, A. (2000). Tiedostaminen ja muutos Paulo Freiren ajattelussa. Systemaattinen analyysi Sorrettujen pedagogiikasta. Helsingin yliopisto, kasvatustieteellinen tiedekunta. http://ethesis.helsinki.fi/julkaisut/kas/kasva/vk/ hannula/tiedosta.pdf

Kirylo, J. (2020). Reinventing Pedagogy of the Oppressed. The Enduring Legacy of Paulo Freire. London: Bloomsbury Academic.

Kurki, L. (2002). Persoona ja yhteisö. Jyväskylä: SoPhi.

Lanas, M., Niinistö, H. \& Suoranta, J. (toim.) (2008). Kriittisen pedagogiikan kysymyksiä 2. Tampere: Tampereen yliopisto. http://urn.fi/urn:isbn:978-951-44-7544-3.
McLaren, P. (2000). Che Guevara, Paulo Freire, and the Pedagogy of the Revolution. Lanham: Rowman \& Littlefield.

McLaren, P. (2009). Che, Freire ja vallankumouksen pedagogiikka. Suom. T. Ahponen ja L. Poser. Helsinki: Like.

Moisio, O-P. \& Suoranta, J. (toim.) (2009). Kriittisen pedagogiikan kysymyksiä 3. Tampere: Tampereen yliopisto. http://urn.fi/urn:isbn:978-951-44-7900-7.

Nivala, E. \& Ryynänen, S. (2019).

Sosiaalipedagogiikka. Helsinki: Gaudeamus.

Peters, M. \& Besley, T. (toim.) (2015). Paulo Freire. The Global Legacy. New York: Peter Lang.

Ryynänen, S. (2011). Nuoria reunoilla.

Sosiaalipedagoginen tutkimus rikollisuuden ja väkivallan keskellä elävien nuorten kasvun tukemisesta brasilialaisissa kansalaisjärjestöissä. Acta Electronica Universitatis Tamperensis 1088. http:// urn.fi/urn:isbn:978-951-44-8482-7.

Suoranta, J. (2005). Radikaali kasvatus. Helsinki: Gaudeamus.

Suoranta, J. (2010). Piilottajan päiväkirja. Helsinki: Into.

Suoranta, J. \& Ryynänen, S. (2014). Taisteleva tutkimus. Helsinki: Into.

Suoranta, J. (2017). C. Wright Millsin sosiologinen elämä. Tampere: Vastapaino.

Suoranta, J. (2019). Paulo Freire. Sorrettujen pedagogi. Helsinki: Into.

Torres, C. (2019). The Wiley Handbook of Paulo Freire. London: Wiley-Blackwell. 